\title{
Specific Merluccius otolith growth patterns related to phylogenetics and environmental factors
}

\author{
A. Lombarte* ${ }^{\top}$, G.J. Torres ${ }^{\dagger}$ and B. Morales-Nin ${ }^{\ddagger}$ \\ *Institut de Ciències del Mar (CMIMA-CSIC), Passeig Marítim 37-49, 08003 Barcelona, Catalonia, Spain. \\ ${ }^{\dagger}$ Centre de Logística i Serveis Marítims (UPC), Escar 6-8, 08039, Barcelona, Catalonia, Spain. \\ ${ }^{\ddagger}$ Institut Mediterrani d'Estudis Avançats (CSIC-UIB), Miquel Marquès 21, 07190 Esporles, Balearic Islands, Spain. \\ $\jmath_{\text {Corresponding author, e-mail: toni@icm.csic.es }}$
}

\begin{abstract}
A comparative morphological study was performed on the otolith growth patterns of 11 species of the genus Merluccius. The otolith growth pattern, based on the radius of the first eight growth increments (GI) from the otolith core, was determined from transverse sections of sagitta otoliths. The structure and periodicity of the GI were identified based on previous knowledge. Two cluster analyses were performed using GI width as a proxy for otolith growth. The first cluster analysis corresponded to the juvenile (immature) period of the fish including the mean width of the first four GI. The second analysis compared the mean width of the next four GI, i.e. those corresponding to mature fish. The results showed an important environmental influence in immature fish; while after maturation, the GI pattern was also related to an endogenous influence depending on the phylogenetic line.
\end{abstract}

\section{INTRODUCTION}

Otoliths are calcium carbonate (aragonite) concretions found in the membranous labyrinths of most teleost fish. Otolith growth and formation involves periodic variation in the deposition and size of their main components (the organic matrix and calcium carbonate crystals), resulting in the formation of microscopic and macroscopic growth increments (Campana \& Neilson, 1985).

However, otoliths not only reflect environmental change, but also genetic variability. The shape and size of the saccular otolith (sagitta) shows clear species-specific and stock-specific characteristics, which allows species to be identified and taxonomic relationships between species to be evaluated (Nolf, 1985).

Consequently, endogenous and exogenous factors exist that determine not only the growth pattern of the otoliths but also their overall shape. Gauldie (1988) suggests that growth increments (GI) are the result of the overall control of otolith size and shape, designed to maintain their functionality as sound transducers. Thus, genetic determinants, fixed in the adaptive process, could influence otolith growth and morphology.

The aim of the present work was to compare the interspecific variability of the GI patterns (increments width) in the sagitta otoliths of the species of the genus Merluccius throughout life from a morphological perspective. The interspecific study of this genus is especially appropriate for otolith GI patterns, because the phylogenetic position of the Merluccius species is well known through studies based on genetic and morphological characters (Ho, 1990; Roldán et al., 1999; Quinteiro et al., 2000; Grant \& Leslie, 2001). All these studies speak of two well-defined phylogenetic lines, one formed by Euro-African species, the other formed by American species. In addition, there is a relationship between morphology of whole otoliths and the phylogeny of the genus (Lombarte \& Castellón, 1991). Moreover, the ontogenic effects, related to otolith function, should appear clearly due to the differentiated species depth distribution with respect to age (Table 1). Even though there is some degree of overlap between young and adult individuals, young fish show the maximum densities in the shallowest range of their distribution, while mature individuals reach deeper areas (Inada, 1981; Recasens et al, 1998).

\section{MATERIALS AND METHODS}

The study was performed with representative samples from 11 species of the genus Merluccius, following the classification proposed by Inada (1981). For each species, only sagitta otoliths that showed at least eight growth increments were analysed (Table 1). Left-hand otoliths were transversely sectioned using standard techniques (Torres et al., 1996). Once the otolith section was digitized, the selected radius was measured and the translucent GI detected. Distances ( $\mathrm{mm}$ ) from the core to each GI were measured and the increment width calculated, taking into account the opaque and contiguous translucent growth increments together. No more than eight GI were analysed to avoid excessive reduction of the sample size. In consequence, the number of samples at each increment is the same. A data matrix was made with the 11 Merluccius species as rows and GI width as columns (Table 2). Cluster analyses with this matrix were performed in order to establish species groups. Linear correlation, that shows a high sensibility to pattern changes, and the UPGMA aggregation algorithm were used (Sokal \& Rohlf, 1962) since the results yield a high cophenetic coefficient.

Hake biology has been extensively studied due to its relevance in fisheries, based on this knowledge the two 
Table 1. Number $(\mathcal{N})$ of Merluccius otoliths analysed, geographical origin of specimens, depth distribution and temperature range by species, and depth distribution and temperature in juvenile area. Mean temperatures are based in Levitus (1982) database.

\begin{tabular}{|c|c|c|c|c|c|c|}
\hline Species & $\mathrm{N}$ & Geographical area & $\begin{array}{l}\text { Depth distribution } \\
\qquad(\mathrm{m})\end{array}$ & $\begin{array}{c}\text { Temperature } \\
\left({ }^{\circ} \mathrm{G}\right)\end{array}$ & $\begin{array}{c}\text { Juvenile } \\
\text { depth range } \\
(\mathrm{m})\end{array}$ & $\begin{array}{c}\text { Juvenile area } \\
\text { temperature } \\
\left({ }^{\circ} \mathrm{C}\right)\end{array}$ \\
\hline M. albidus & 12 & Gulf Stream (USA) & $100-1100$ & $10-18$ & $200-400$ & $14-16$ \\
\hline M. australis & 23 & SE Pacific (Chile) & $50-800$ & $4-9$ & $200-300$ & $6-8$ \\
\hline M. bilinearis & 7 & NW Atlantic (Canada) & $50-700$ & $5-12$ & $80-200$ & $8-10$ \\
\hline M. capensis & 10 & SE Atlantic (Namibia) & $50-400$ & $8-13$ & $100-200$ & $10-11$ \\
\hline M. gayi & 17 & SE Pacific (Chile) & $50-600$ & $6-12$ & $100-200$ & $10-11$ \\
\hline M. hubbsi & 10 & SW Atlantic (Argentina) & $50-500$ & $5-12$ & $100-200$ & $9-11$ \\
\hline M. merluccius & 8 & Mediterranean (Catalonia) & $50-1000$ & $10-15$ & $100-200$ & $12-13$ \\
\hline M. paradoxus & 9 & SE Atlantic (Namibia) & $150-1000$ & $4-9$ & $200-400$ & $7-9$ \\
\hline M. polli & 8 & E Atlantic (Guinean Gulf) & $100-600$ & $6-14$ & $200-300$ & $9-10$ \\
\hline M. productus & 6 & NE Pacific (Canada) & $50-1000$ & $4-8$ & $100-300$ & $6-8$ \\
\hline M. senegalensis & 10 & NE Atlantic (Mauritania) & $50-500$ & $6-13$ & $100-300$ & $9-10$ \\
\hline
\end{tabular}

Table 2. Means and standard deviations of first eight growth increments width from the Merluccius studied species.

\begin{tabular}{|c|c|c|c|c|c|c|c|c|}
\hline \multicolumn{9}{|c|}{ Width (mm) } \\
\hline Species & PR & DR & $\mathrm{R} 1$ & $\mathrm{R} 2$ & R3 & $\mathrm{R} 4$ & R5 & R6 \\
\hline & \multicolumn{8}{|c|}{ Means } \\
\hline M. albidus & 0.26 & 0.18 & 0.26 & 0.28 & 0.28 & 0.31 & 0.30 & 0.27 \\
\hline M. australis & 0.25 & 0.17 & 0.21 & 0.20 & 0.21 & 0.21 & 0.19 & 0.19 \\
\hline M. bilinearis & 0.25 & 0.14 & 0.18 & 0.19 & 0.23 & 0.22 & 0.24 & 0.21 \\
\hline M. capensis & 0.25 & 0.18 & 0.22 & 0.28 & 0.23 & 0.23 & 0.19 & 0.18 \\
\hline M. gayi & 0.23 & 0.16 & 0.19 & 0.24 & 0.25 & 0.22 & 0.24 & 0.19 \\
\hline M. hubbsi & 0.24 & 0.19 & 0.21 & 0.24 & 0.25 & 0.21 & 0.20 & 0.18 \\
\hline M. merluccius & 0.26 & 0.17 & 0.30 & 0.27 & 0.26 & 0.24 & 0.23 & 0.24 \\
\hline M.paradoxus & 0.27 & 0.17 & 0.21 & 0.23 & 0.20 & 0.19 & 0.17 & 0.17 \\
\hline M.polli & 0.24 & 0.16 & 0.21 & 0.25 & 0.24 & 0.21 & 0.15 & 0.17 \\
\hline M. productus & 0.25 & 0.16 & 0.19 & 0.20 & 0.21 & 0.20 & 0.24 & 0.16 \\
\hline \multirow[t]{3}{*}{ M. senegalensis } & 0.23 & 0.18 & 0.18 & 0.21 & 0.21 & 0.20 & 0.16 & 0.15 \\
\hline & PR & DR & $\mathrm{R} 1$ & R2 & $\mathrm{R} 3$ & $\mathrm{R} 4$ & R5 & R6 \\
\hline & \multicolumn{8}{|c|}{ Standard deviations } \\
\hline M. albidus & 0.07 & 0.10 & 0.09 & 0.06 & 0.10 & 0.13 & 0.08 & 0.08 \\
\hline M. australis & 0.08 & 0.10 & 0.12 & 0.11 & 0.10 & 0.09 & 0.06 & 0.09 \\
\hline M. bilinearis & 0.08 & 0.07 & 0.11 & 0.10 & 0.11 & 0.10 & 0.06 & 0.04 \\
\hline M. capensis & 0.06 & 0.07 & 0.09 & 0.08 & 0.06 & 0.11 & 0.04 & 0.05 \\
\hline M. gayi & 0.08 & 0.08 & 0.08 & 0.10 & 0.09 & 0.11 & 0.08 & 0.06 \\
\hline M. hubbsi & 0.10 & 0.10 & 0.10 & 0.10 & 0.10 & 0.08 & 0.06 & 0.03 \\
\hline M. merluccius & 0.08 & 0.09 & 0.19 & 0.09 & 0.12 & 0.09 & 0.03 & 0.04 \\
\hline M.paradoxus & 0.07 & 0.08 & 0.07 & 0.12 & 0.07 & 0.06 & 0.05 & 0.05 \\
\hline M. polli & 0.06 & 0.11 & 0.07 & 0.08 & 0.08 & 0.06 & 0.02 & 0.02 \\
\hline M. productus & 0.06 & 0.08 & 0.09 & 0.15 & 0.11 & 0.09 & 0.03 & 0.03 \\
\hline M. senegalensis & 0.07 & 0.09 & 0.08 & 0.09 & 0.09 & 0.07 & 0.03 & 0.05 \\
\hline
\end{tabular}

PR, pelagic ring; DR, demersal ring; Rn, annuli.

first clear GI in otoliths were not considered as annual, also it is known that hake reach maturity at 3-4 years of age (Nelson \& Larkins, 1970; Bezzi et al., 1995; MoralesNin et al., 1998, inter alia). From this moment on, otolith shape is well defined, allowing classification at the species level (Lombarte \& Castellón, 1991). So, two different cluster analyses were performed:

1. Analysis of the first four mean GI widths (pelagic ring $(\mathrm{PR})$, demersal ring (DR), lst annulus (R1) and 2nd annulus (R2)) corresponding to the juvenile period.
2. Comparison of the mean width of the next four GI (3rd annulus (R3), 4th annulus (R4), 5th annulus (R5) and 6 th annulus $(\mathrm{R} 6))$ corresponding to the adult period (during and after the first period of maturity).

\section{RESULTS}

Otolith growth pattern

All species showed some common features with respect to the otolith growth pattern, as indicated by the GI 

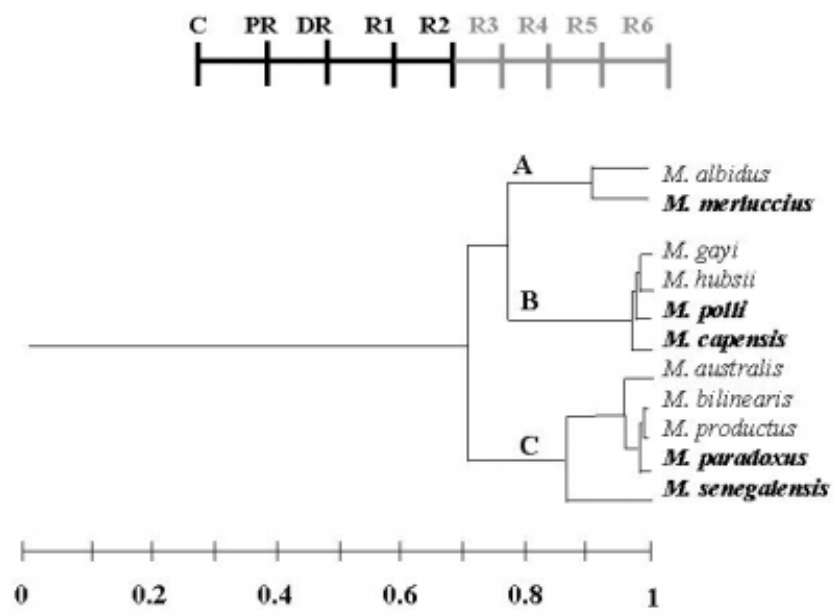

Figure 1. Cluster analysis (linear correlation, UPGMA) indicating relationships shown by the four first growth increments width (PR to R2) of the sagittae. Cophenetic correlation coefficient, $\mathrm{CCC}=0.71$. Chaining, $\mathrm{C}=0.31$. Minimum linear correlation, $\mathrm{MC}=0.71$. $\mathrm{PR}$, pelagic ring; $\mathrm{DR}$, demersal ring; Rn, annuli. The species of the EuroAfrican group are indicated in bold.

widths ('lable 2). While pelagic GI (PR) and those of the 2nd (R2) and 3rd annulus (R3) were the widest GI, the width between the PR and DR was narrow in all species. PR and DR widths had a lower standard deviation than the other GI.

\section{Cluster analysis of growth increments width}

The two cluster analyses showed a high cophenetic correlation coefficient (CCG) (between 0.71 and 0.86) and a low chaining $(\mathrm{C})$ (between 0.31 and 0.44 ), which indicated that valid groupings had been detected.

The multivariate analysis of the first four GI width (Figure 1) showed three groups of species. The minimum
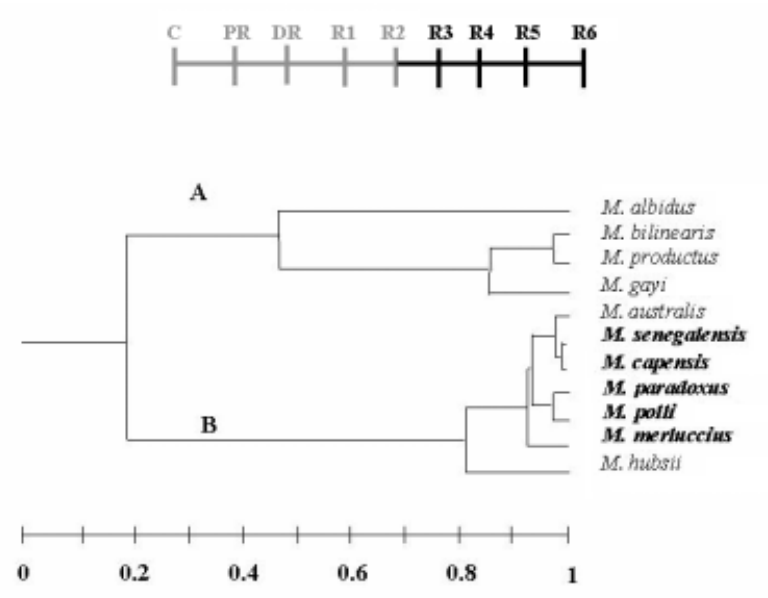

Figure 2. Cluster analysis (linear correlation, UPGMA) indicating relationships shown by the four next growth increments width (R3 to R6). Cophenetic correlation coefficient, $\mathrm{CCC}=0.86$. Chaining, $\mathrm{C}=0.44$. Minimum linear correlation, $\mathrm{MC}=0.18$. $\mathrm{PR}$, pelagic ring; $\mathrm{DR}$, demersal ring; $\mathrm{Rn}$, annuli. The species of the Euro-African group are indicated in bold. correlation (MC) between groups was 0.71. Group A was formed by Merluccius albidus and M. merluccius, characterized by having greater average values of GI width in the 1st (R1) and 2nd annuli (R2) (Table 2). Group B was formed of M. capensis, M. gayi, M. hubsii and M. polli, and was characterized by having intermediate values of GI width in the juvenile period (Table 2). Group G was formed by $M$. australis, $M$. bilinearis, $M$. paradoxus, $M$. productus and $M$. senegalensis, and was characterized by having the thinnest GI in the lst (R1) and 2nd (R2) annuli (Table 2).

Analysis of the R3 to R6 GI width showed a very different pattern (Figure 2). Two, clearly separate groups were observed and the linear correlation between them was low $(\mathrm{MC}=0.18)$. Group A contained the species M. albidus, M. bilinearis, M. gayi and M. productus, and was characterized by having very homogeneous GI width between the 3rd (R3), 4th (R4) and 5th (R5) annuli. However, the 6th annulus (R6) showed an important decrease in width in all species of group A (Table 2). Group B, formed by $M$. australis, M. capensis, M. hubsii, M. merluccius, M. paradoxus, M. polli, and M. senegalensis, was characterized by a decrease in growth from R3 to R6 (Table 2).

\section{DISGUSSION}

There are several abiotic and biotic characteristics of the particular niche occupied by each Merluccius species that influence the growth of the otolith (Morales-Nin, 1987; Secor \& Dean, 1989), which is closely related to the temperature and depth (Simkiss, 1974; Secor \& Dean, 1989). Species or populations from more temperate waters have relatively larger and heavier otoliths than those from cold water (Gauldie, 1993; Lombarte \& Lleonart, 1993; Torres et al., 2000). However, a certain uncoupling in relation with external factors exists due to stability in the otolith growth (Mosegaard et al., 1988).

This study is the first attempt to relate the inner growth patterns of the otoliths to genetic and environmental factors. Our hypothesis is that they reflect the overall otolith growth along time and thus, they can provide an accurate record of otolith development. The results referring to the first otolith growth period, which includes the initial phases of life up to two years of age corresponding to juveniles, suggest that environment is the main influence upon otolith GI width. The maximum juvenile abundance is located between 100 and $300 \mathrm{~m}$ on the continental shelf and upper slope (Inada, 1981). Thus, the greater otolith growth observed in Merluccius albidus and M. merluccius, from the Gulf Stream and the western Mediterranean respectively, could be related to development in warmer waters. Merluccius albidus is bound to the warm current of the Gulf with a temperature at the recruitment depth (200 m) ranging between 16 and $18^{\circ} \mathrm{C}$ (Inada, 1981; Levitus, 1982), while M. merluccius lives in Mediterranean waters with very little seasonal temperature variation, and with recruitment areas at about $150 \mathrm{~m}$ and water temperatures of around $13^{\circ} \mathrm{C}$ (Recasens et al., 1998). The species with average width GI, such as $M$. capensis, $M$. gayi and M. hubsii, are characterized by their belonging to shallow waters and by being bound to cold currents (Inada, 1981; 
Levitus, 1982). Merluccius polli, which shares a cluster with the three previous species, lives in deeper, equatorial waters (Ramos-Martos \& Fernández-Peralta, 1995). The temperature of the recruitment areas of the four species ranges between 8 and $11^{\circ} \mathrm{C}$ (Levitus, 1982). The group formed by $M$. australis, $M$. bilinearis, $M$. paradoxus, $M$. productus and $M$. senegalensis, which have the smallest width between the first four GI, are found in cold waters and/or at greater depths than the other members of the genus. The temperature range of the recruitment areas of the four species is between 6 and $10^{\circ} \mathrm{C}$ (Nichy, 1969; Nelson \& Larkins, 1970; Botha, 1971; Inada, 1981; Levitus, 1982; Aguayo-Hernández, 1995; Bezzi et al., 1995; Gordoa et al., 1995; Methot \& Dorn, 1995; Ramos-Martos \& Fernández-Peralta, 1995). In each of the three groups there are species that correspond to the two phylogenetic lines (Euro-African and American). The thinner width of the second ring (DR), corresponding to the transition from pelagic to demersal habitat, might be due to a shorter formation period and physiological stress related to habitat and dietary change (Morales-Nin, 1986).

Analysis of the widths between the 3rd (R3) and 6th (R6) GI shows a very different classification pattern to that of the first four GI. Based on this, two groups of species can be distinguished. One is formed exclusively by American species (M. albidus, M. bilinearis, M. gayi and $M$. productus), and is characterized by having very similar widths between the 3rd (R3) and 5th (R5) annuli. The second group includes all the species of the Euro-African group (M. capensis, M. merluccius, M. paradoxus, M. polli and $M$. senegalensis), as well as two more southern American species (M. australis and $M$. hubsii). All are characterized by a continuous decrease in the thickness of the most external GI. Both groups show great heterogeneity in relation to environmental parameters. This partially reflects the two phylogenetic lines (Euro-African and American) of the genus (Ho, 1990; Grant \& Leslie, 2001). In support of the genetic influence on otolith growth, it is necessary to stress that two pairs of closely related species, such as $M$. polli-M. paradoxus, and $M$. senegalensisM. capensis (Roldán et al., 1999), show very similar growth patterns. However, the grouping of the two southern American species with their Euro-African counterparts indicates other factors might affect otolith growth.

The results suggest that the importance of phylogenetic and environmental influences vary depending on the life phase of the fish and their ontogenic development. The existence of a possible relationship between the GI pattern and the phylogenetic line might support the hypothesis of a genetic control for otolith growth (Gauldie, 1988).

Walter Norbis, Herbert Nión, Edgardo Di Giácomo, Vilma Ojeda, David Garland, Laura Recasens, Ana Ramos, Pere Oliver, Carmen Piñeiro, Joseph J. Hunt, John L. Butler, G.A. McFarlane and A. Flesher are thanked for their invaluable help in making the otolith samples available. We thank Jordi Lleonart for help with statistical analysis. This work was supported by the EU FAIR project CT 95-0655. Gabriel Torres's contribution was funded under the doctoral fellowship grant provided by the Spanish International Co-operation Agency (AECI) and the Latin-American-Catalonian Co-operation Institute (ICCI).

\section{REFERENCES}

Aguayo-Hernández, M., 1995. Biology and fisheries of Chilean hakes (M. gayi and M. australis). In Hake: fisheries ecology and markets, (ed. J. Alheit and T.J. Pitcher), pp. 305-338. London: Chapman \& Hall Books Series.

Bezzi, S.I., Verazay, G.A. \& Dato, G.V., 1995. Biology and fisheries of Argentine hakes (M. hubbsi and M. australis). In Hake: fisheries ecology and markets (ed. J. Alheit and T.J. Pitcher), pp. 239-267. London: Chapman \& Hall Books Series.

Botha, L., 1971. Growth and otolith morphology of the Cape hakes Merluccius capensis Cast. and M. paradoxus Franca. Investigational Report Division Sea Fisheries South Africa, 97, 1-32.

Campana, S.E. \& Neilson, J.D., 1985. Microstructures of fish otoliths. Canadian Fournal of Fisheries and Aquatic Sciences, 42, 1014-1032.

Gauldie, R.W., 1988. Function, form and time-keeping properties of fish otoliths. Comparative Biochemistry and Physiology, 91, 395402.

Gauldie, R.W., 1993. Continuous and discontinuous growth in the otolith of Macruronus novaezelandiae (Merlucciidae: Teleostei). Fournal of Morphology, 216, 271-294.

Gordoa, A., Macpherson, E. \& Olivar, M.P., 1995. Biology and fisheries of Namibian hake (M. paradoxus and M. capensis). In Hake: fisheries ecology and markets (ed. J. Alheit and T.J. Pitcher), pp. 49-88. London: Chapman \& Hall Books Series.

Grant, W.S. \& Leslie, R.W., 2001. Inter-ocean dispersal is an important mechanism in the zoogeography of hakes (Pisces: Merluccius spp.). Fournal of Biogeography, 28, 699-721.

Ho, J.S., 1990. Phylogeny and biogeography of hakes (Merluccius; Teleostei): a cladistic analysis. Fisheries Bulletin, 84, 95-104.

Inada, T., 1981. Studies on the merluccid fishes. Bulletin of Far Seas Research Laboratory (Shimizu), 18, 1-172.

Levitus, S., 1982. Climatological atlas of the world ocean, NOAA Professional. Paper 13, pp. 1-73. Washington DC: US Government Printing Office.

Lombarte, A. \& Castellón, A., 1991. Interspecific and intraspecific variability in the genus Merluccius as determined by image analysis. Canadian Fournal of Zoology, 69, 2442-2449.

Lombarte, A. \& Lleonart, J., 1993. Otolith size changes related with body growth, habitat depth and temperature. Environmental Biology of Fishes, 37, 297-306.

Methot, R.D. \& Dorn, M.W., 1995. Biology and fisheries of North Pacific hake (M. productus). In Hake: fisheries ecology and markets (ed. J. Alheit and T.J. Pitcher), pp. 389-414. London: Chapman \& Hall Books Series.

Morales-Nin, B., 1986. Structure and composition of otoliths of Cape hake Merluccius capensis. South African Journal of Marine Sciences, 4, 3-10.

Morales-Nin, B., 1987. Influence of environmental factors on microstructure of otoliths of three demersal fish species caught off Namibia. In The Benguela and comparable ecosystems (ed. A.I.L. Payne et al.). South African fournal of Marine Sciences, 5, 255-262.

Morales-Nin, B., Torres, G.J., Lombarte, A. \& Recasens, L., 1998. Otolith growth and age estimation in the European hake. Journal of Fish Biology, 53, 1155-1168.

Mosegaard, H., Svedäng, H. \& Taberman, K., 1988. Uncoupling of somatic and otolith growth rates in Arctic char (Salvelinus alpinus) as an effect of differences in temperature response. Canadian Fournal of Fisheries and Aquatic Sciences, 45, 1514-1524.

Nelson, M.O. \& Larkins, H.A., 1970. Distribution and biology of Pacific hake: a synopsis. Circular. Fish and Wildlife Service. Washington, DC, 332, 23-33.

Nichy, F.E., 1969. Growth patterns on otolith from young silver hake, Merluccius bilinearis (Mitchell). International Commission for North-west Atlantic Fisheries Research Bulletin, 6, 107-117.

Nolf, D., 1985. Otolith piscium. In Handbook of paleoichthyology, vol. 10 (ed H.P. Schultze), pp. 1-145. Stuttgart and New York: Gustav Fisher Verlag. 
Quinteiro, J., Vidaland, R. \& Rey-Méndez, M., 2000. Phylogeny and biogeographic history of hake (genus Merluccius), inferred from mitochondrial DNA control-region sequences. Marine Biology, 136, 163-174.

Ramos-Martos, A. \& Fernández-Peralta, L., 1995. Biology and fisheries of North-west African hakes (M. merluccius, M. senegalensis and M. polli). In Hake: fisheries ecology and markets (ed. J. Alheit and T.J. Pitcher), pp. 89-124. London: Chapman \& Hall Books Series.

Recasens, L., Lombarte, A., Morales-Nin, B. \& Torres, G.J., 1998. Spatiotemporal variation in the population structure of the European hake, in the NW Mediterranean. Fournal of Fish Biology, 53, 387-401.

Roldán, M.I., García-Marín, J.L., Utter, F.D. \& Pla, C., 1999. Genetic relationship among Merluccius species. Heredity, 83, 79-86.

Secor, D.H. \& Dean, J.M., 1989. Somatic growth effects on the otolith-fish size relationship in young pond-reared striped bass, Morone saxatilis. Canadian Fournal of Fisheries and Aquatic Sciences, 46, 113-121.
Simkiss, K., 1974. Calcium metabolism of fish in relation to ageing. In Ageing of fish (ed. T.B. Bagenal), pp. 1-12. Old Woking: Unwin Brothers.

Sokal, R.R. \& Rohlf, F.J., 1962. The comparison of dendograms by objective methods. Taxon, 11, 33-40.

Torres, G.J., Lombarte, A. \& Morales-Nin, B., 2000. Size and shape otolith variability to identify geographical intraspecific differences in three species of genus Merluccius (M. gayi, M. hubbsi and M. merluccius). Fournal of the Marine Biological Association of the United Kingdom, 80, 333-342.

Torres, G.J., Norbis, W. \& Lorenzo, M.I., 1996. Variations in the measurements of argentine hake (Merluccius hubbsi) growth increments otoliths during their first-year: evidence for stocks separation? Scientia Marina, 60, 331-338.

Submitted 10 June 2002. Accepted 13 February 2003. 